\title{
Macrophyte-related shifts in the nitrogen and phosphorus contents of the different trophic levels in a biomanipulated shallow lake
}

\author{
Ellen van Donk ${ }^{1}$, Ramesh D. Gulati ${ }^{2}$, Arjen Iedema ${ }^{1} \&$ John T. Meulemans ${ }^{3}$ \\ ${ }^{1}$ Department of Nature Conservation, Agricultural University, P.0. Box 8080, 6700 DD Wageningen, The \\ Netherlands; ' Limnological Institute, 'Vijverhof' Laboratory, Rijksstraatweg 6, 3631 AC Nieuwershis, \\ The Netherlands; ${ }^{3}$ AquaSense, P.O. Box 41125, 1009 EC Amsterdam, The Netherlands
}

Key words: whole-lake experiment, biomanipulation, macrophytes, nitrogen and phosphorus retention, trophic levels

\section{Abstract}

Lake Zwemlust, a small highly eutrophic lake, was biomanipulated without reducing the external nutrient loading, and the effects were studied for four years. In this paper we pay special attention to the shifts in relative distribution of nitrogen and phosphorus in the different trophic levels and to the changes in growth limitation of the autotrophs.

Despite of the high external nutrient loads to the lake ( $c a 2.4 \mathrm{~g} \mathrm{P} \mathrm{m}^{-2} \mathrm{y}^{-1}$ and $9.6 \mathrm{~g} \mathrm{~N} \mathrm{~m}^{-2} \mathrm{y}^{-1}$ ), the cffects of biomanipulation on the lake ccosystem werc pronounced. Beforc biomanipulation no submerged vegetation was present in the lake and $\mathrm{P}$ and $\mathrm{N}$ were stored in the phytoplankton $(44 \% \mathrm{~N}$, $47 \% \mathrm{P})$, fish $(33 \% \mathrm{~N}, 9 \% \mathrm{P})$ and in dissolved forms $(23 \% \mathrm{~N}, 44 \% \mathrm{P}) . \mathrm{P}$ and $\mathrm{N}$ contents in sediments were not determined. In the spring and summer following the biomanipulation (1987), zooplankton grazing controlled the phytoplankton biomass and about $90 \%$ of $\mathrm{N}$ and $\mathrm{P}$ were present in dissolved form in the water. From 1988 onwards submerged macrophyte stands continue to thrive, reducing the ammonium and nitrate concentrations in the water below detection levels. In July 1989 storage of $\mathrm{N}$ and $\mathrm{P}$ in the macrophytes reached $86 \%$ and $80 \%$, respectively. Elodea nuttallii (Planchon) St.John, the dominant species in 1988 and 1989, acted as sink both for $\mathrm{N}$ and $\mathrm{P}$ during spring and early summer, withdrawing up to $c a 60 \%$ of its $\mathrm{N}$ and $\mathrm{P}$ content from the sediment. At the end of the year only part of the $\mathrm{N}$ and $\mathrm{P}$ from the decayed macrophytes ( $\mathrm{ca} 30 \%$ of $\mathrm{N}$ and $60 \%$ of $\mathrm{P}$ ) was recovered in the water phase of the ecosystem (chiefly in dissolved forms). The rest remained in the sediment, although some $\mathrm{N}$ may have been released from the lake by denitrification.

In summer 1990 only $30 \%$ of the $\mathrm{N}$ and $\mathrm{P}$ was found in the macrophytes (dominant species Ceratophyllum demersum L.), while ca $30 \%$ of $\mathrm{N}$ and $\mathrm{P}$ was again stored in phytoplankton and fish.

\section{Introduction}

Restoration of shallow and turbid eutrophic lakes by means of nutrient reduction is often retarded or even prevented by powerful buffering mechanisms. Biomanipulation may, therefore, be essen- tial to switch shallow lakes from the phytoplankton-dominated state to a clear water state with submerged macrophytes, despite of a considerable nutrient reduction (Moss, 1990; Scheffer, 1990). Submerged macrophytes may act as an ecotone zone by changing the nutrient retention 
and cycling in the food-web and by inducing longterm stability (Naiman et al., 1989).

Biomanipulation of eutrophic lakes has mainly focussed on the removal or restructuring of planktivorous fish populations to affect changes in the zooplankton from a community dominated by small-bodied to one dominated by large-bodied cladocerans, particularly of the genus Daphnia (Shapiro \& Wright, 1984; Gulati, 1990). Intense grazing by the large-bodied zooplankters can then lead to large-scale reductions in phytoplankton biomass and the consequent increases in water clarity and submerged macrophyte population. Benndorf (1990) stated that restoration of eutrophied water bodies, having a high external nutrient load, seems feasible only if two strategies, i.e. nutrient reduction and biomanipulation, are integrated.

To study the effects of biomanipulation separately from nutrient reduction, the fish community in a small highly eutrophic lake was altered without changing the external nutrient loading. The effects of this food-web manipulation were monitored for four years and compared with the situation before restoration. Due to changes in food-web interactions, changes in nutrient dynamics were likely to occur (Boers et al., 1991). Consequently these changes may have their effects on the factors controlling the growth of phytoplankton and macrophytes. In this paper the shifts in relative distribution of nitrogen and phosphorus in the different trophic levels of the lake and the changes in growth limitation of the autotrophs are discussed.

\section{Site description}

Lake Zwemlust is a small water body (1.5 ha), with a mean depth of $1.5 \mathrm{~m}$ and a maximum depth of $2.5 \mathrm{~m}$. It is located in Nieuwersluis in the Province of Utrecht, The Netherlands. The water quality in the lake had deteriorated (until the biomanipulation measure), due to nutrient-rich seepage water from the polluted River Vecht located approximately $50 \mathrm{~m}$ from the lake. Besides precipitation, seepage water is the main source of the lake's water input. Prior to biomanipulation the lake was highly turbid, especially in summer (Secchi-depth, $0.3 \mathrm{~m}$ ), primarily because of high biomass of the cyanobacterium Microcystis aeruginosa Kütz.. The recurrent and persistent blooms of algae led to deterioration of the light climate and a complete disappearance of submerged macro-vegetation. Only small strips of emerged plants (Phragmites australis Cav. and Nuphar lutea L.) were present in the littoral zone of the lake (Van Donk et al., 1989). Consequently, an alteration in the structure of the fish community occurred: the piscivore pike (Esox lucius L.) vanished and the planktivore bream (Abramis brama L.) became dominant.

In March 1987, the lake was emptied by pumping out the water to facilitate complete fish elimination. Planktivorous and benthivorous species, which were predominant, were collected by seineand electro-fishing. The total mass of fish removed, $c a 1500 \mathrm{~kg}$, included about $75 \%$ bream (length $10-15 \mathrm{~cm}$ ). After the lake was refilled by seepage, in ca 3 days, it was restocked with juvenile fish: $1600 \mathrm{O}^{+}$pike, measuring $4 \mathrm{~cm}$, and 140 rudd (Scardinius erythrophthalmus L.) measuring 9-13 cm fork length. The offsprings of the latter fish were meant to serve as food for pike. The biomanipulation measures are discussed extensively by Van Donk et al. (1989).

\section{Methods}

In order to quantify the external $\mathrm{P}$ and $\mathrm{N}$ loads to the lake, the hydrodynamics of the lake had to be studied. Six piezometers were installed to measure the hydraulic gradient of the water tables. Hydraulic conductance was estimated through pump test, and hydrogeologic boundaries established. Piezometers were also used to analyse the $\mathrm{P}$ and $\mathrm{N}$ contents of the ground water. Additionally the water levels were read twice a week; simultaneously groundwater and surface water samples were taken for chemical analyses. From these data the net amounts of the incoming $P$ and $\mathrm{N}$ in the seepage water were calculated. The nutrient load to the lake due to direct deposition 
(wet and dry) was calculated from meteorological data obtained from a station at De Bilt, east of the city of Utrecht. Chemical analyses of the lake sediment were not carried out due to its complexity. Therefore, the sediment is regarded as the closing entry of the balance. The net external nutrient load $\left(\mathrm{L}_{\text {net }}\right)$ was calculated from the total external nutrient load $\left(\Sigma \mathrm{L}_{\text {ext }}\right)$ minus the sum of all nutrient outputs $\left(\Sigma \mathrm{L}_{\text {out }}\right)$ :

$$
\Sigma \mathrm{L}_{\text {ext }}-\Sigma \mathrm{L}_{\text {out }}=\mathrm{L}_{\text {net }} \text {. }
$$

The internal nutrient loading (release and uptake of $\mathrm{N}$ and $\mathrm{P}$ from the sediment) was estimated from nutrient budget data according to Cooke et al. (1977). For the period April-September 1989 the net internal P and $N$ loads to the lake ecosystem $\left(\mathrm{L}_{\text {int }}\right)$ were estimated from the change in $\mathrm{N}$ and $\mathrm{P}$ content of the lake $(\delta \mathrm{E}=$ sum of amounts of $P$ and $\mathrm{N}$ built up in the different compartments of the ecosystem, excluding the sediment) from April 1989 to September 1989, minus the net external load to the lake $\left(\mathrm{L}_{\text {net }}\right)$ over this period:

$$
\delta \mathrm{E}-\mathrm{L}_{\text {net }}=\mathrm{L}_{\text {int }} .
$$

Denitrification loss may produce an underestimation for the internal $\mathrm{N}$ load to the lake. For procedures of sampling and analyses of $\mathrm{N}$ and $\mathrm{P}$ in water, phytoplankton, zooplankton, macrophytes and fish, see Van Donk et al. (1989) and Ozimek et al. (1990).

To assess the factors limiting the growth of phytoplankton and submerged macrophytes from 1987 to 1990 , community enrichment bioassays were performed at the in situ temperature and prevailing light-dark cycle. The procedures for these bioassay experiments are described in Van Donk et al. (1988, 1990) and Ozimek et al. (1990).

Two cages $(4 \mathrm{~m}$ length, $1 \mathrm{~m}$ width and $0.6 \mathrm{~m}$ height), clothed with $1.5 \mathrm{~cm}$ mesh wire-netting, were stripped of fish and placed at the lake bottom. In these enclosures the growth of the macrophytes was followed without the interference of larger fish (grazing or grubbing up the sediment) and herbivorous waterfowl.

\section{Results}

\section{General developments}

The mean yearly net inflow of water to the lake of $c a 20000 \mathrm{~m}^{3}$ results in a water residence time of $c a 9$ months. The external loads of $\mathrm{N}$ and $\mathrm{P}$ were high and did not change discernibly during the study years: $c a \quad 2.4 \mathrm{~g} \mathrm{P} \mathrm{m}^{-2} \mathrm{y}^{-1}$ and $9.6 \mathrm{~g} \mathrm{~N} \mathrm{~m}^{-2} \mathrm{y}^{-1}$ (including a load from wet and dry deposition of $c a 0.2 \mathrm{~g} \mathrm{P} \mathrm{m}^{-2} \mathrm{y}^{-1}$ and $5.3 \mathrm{~g} \mathrm{~N} \mathrm{~m}^{-2} \mathrm{y}^{-1}$ ).

After the biomanipulation, despite of the high and unchanged $\mathrm{P}$ and $\mathrm{N}$ loads to the lake, the effects on the structure of the ecosystem were marked. The Secchi disc depth increased and reached the lake bottom $(2.5 \mathrm{~m})$ in the summers following biomanipulation. The mean chlorophyll concentration was reduced from $250 \mu \mathrm{g} \mathrm{l}^{-1}$ in 1986 (before biomanipulation) to $5-13 \mu \mathrm{g} \mathrm{1^{-1 }}$ after biomanipulation. The submerged macrophytes responded rapidly to the improved light conditions (Ozimek et al., 1990; Van Donk et al., 1990). In the summer of 1988 macrophytes occupied $\mathrm{ca} 70 \%$ of the lake bottom (total biomass ca $87 \mathrm{~g} \mathrm{DW} \mathrm{m}^{-2}$ ) and almost $100 \%$ in summer of 1989 (total biomass ca $200 \mathrm{~g} \mathrm{DW} \mathrm{m}^{-2}$ ). Elodea nuttallii was the dominant species in 1988 and 1989; it contributed $70 \%$ and $82 \%$, respectively, to the total macrophyte biomass. In the summer of 1990 , however, the total biomass of the macrophytes declined ( $c a .57 \mathrm{~g} \mathrm{DW} \mathrm{m}^{-2}$ ) and Ceratophyllum demersum became the dominant species (Fig. 1). The highest biomass of largebodied zooplankton was found directly after the biomanipulation, ca 350 ind. $1^{-1}$ of daphnids in spring 1987.

However in the following years, the contribution of the zooplankton to the total biomass decreased (Gulati, 1989; 1990). Further, a shift in the dominance from daphnids to bosminids was observed from 1987-1989 to 1990.

The rudd population, stocked after the biomanipulation, gradually increased from $50 \mathrm{~kg} \mathrm{ha}^{-1}$ (all $0^{+}$rudd) in 1988 to $398 \mathrm{~kg} \mathrm{ha}^{-1}$ (including ca $125 \mathrm{~kg} \mathrm{ha}^{-1} 0^{+}$rudd) in $1990.0^{+}$ Rudd is mainly planktivorous, not benthivorous, 


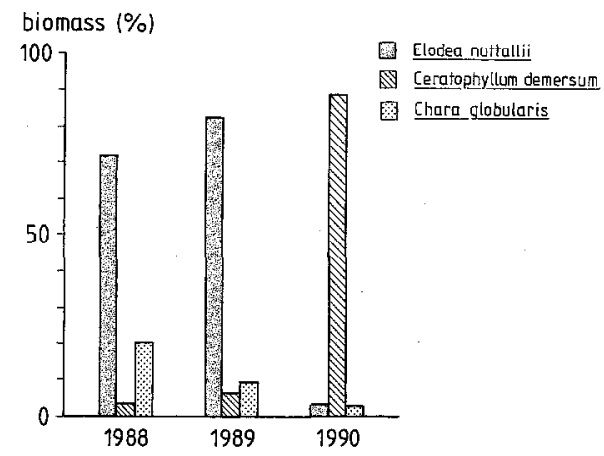

Fig. 1. The contribution of the different species to the total macrophyte biomass after biomanipulation in August 1988, 1989 and 1990 in Lake Zwemlust.

and $1^{+}$and $2^{+}$rudd can also feed on macrophytes (Klein-Breteler, 1991). The pike population decreased first, from $58 \mathrm{~kg} \mathrm{ha}^{-1}$ in 1988 to $18 \mathrm{~kg} \mathrm{ha}^{-1}$ in 1989 , but rose again to $44 \mathrm{~kg} \mathrm{ha}^{-1}$ in 1990 (Klein-Breteler, 1991).

\section{Nutrient distribution}

The distribution of $\mathrm{N}$ and $\mathrm{P}$ over the different trophic levels of the lake, measured at the end of August in the years before (1986) and after the biomanipulation (1987-1990), are given in Fig. 2 . Before the biomanipulation, no submerged vegetation was present and $\mathrm{P}$ and $\mathrm{N}$ were stored in the phytoplankton $(44 \% \mathrm{~N}, 47 \% \mathrm{P})$, fish $(33 \% \mathrm{~N}$, $9 \% \mathrm{P})$ and in dissolved forms $(23 \% \mathrm{~N}, 44 \% \mathrm{P})$. $\mathrm{P}$ and $\mathrm{N}$ contents of sediments were not determined. In the summer immediately following the biomanipulation (1987), N and P were mainly dissolved in the water as SRP (Soluble Reactive Phosphorus), $\mathrm{NH}_{4}-\mathrm{N}, \mathrm{NO}_{3}-\mathrm{N}$ and organic- $\mathrm{N}$, which form $\mathrm{ca} 90 \%$ of the total $\mathrm{N}$ and $\mathrm{P}$. From 1988 onwards the spring and summer concentrations of both $\mathrm{NH}_{4}-\mathrm{N}$ and $\mathrm{NO}_{3}-\mathrm{N}$ decreased below detection levels, while the SRP concentration only decreased slightly and was still very high $\left(>0.3 \mathrm{mg} \mathrm{l}^{-1}\right)$. The storage of $\mathrm{N}$ and $\mathrm{P}$ in the macrophytes above the sediment increased enormously, with the highest percentages in 1989 ( $\mathrm{ca}$ $86 \%$ of total $\mathrm{N}$ and $80 \%$ of $\mathrm{P}$ in $E$. nuttallii). In 1990 only $30 \%$ of the $\mathrm{N}$ and $\mathrm{P}$ was found in the macrophytes (mainly in $C$. demersum), while $c a$

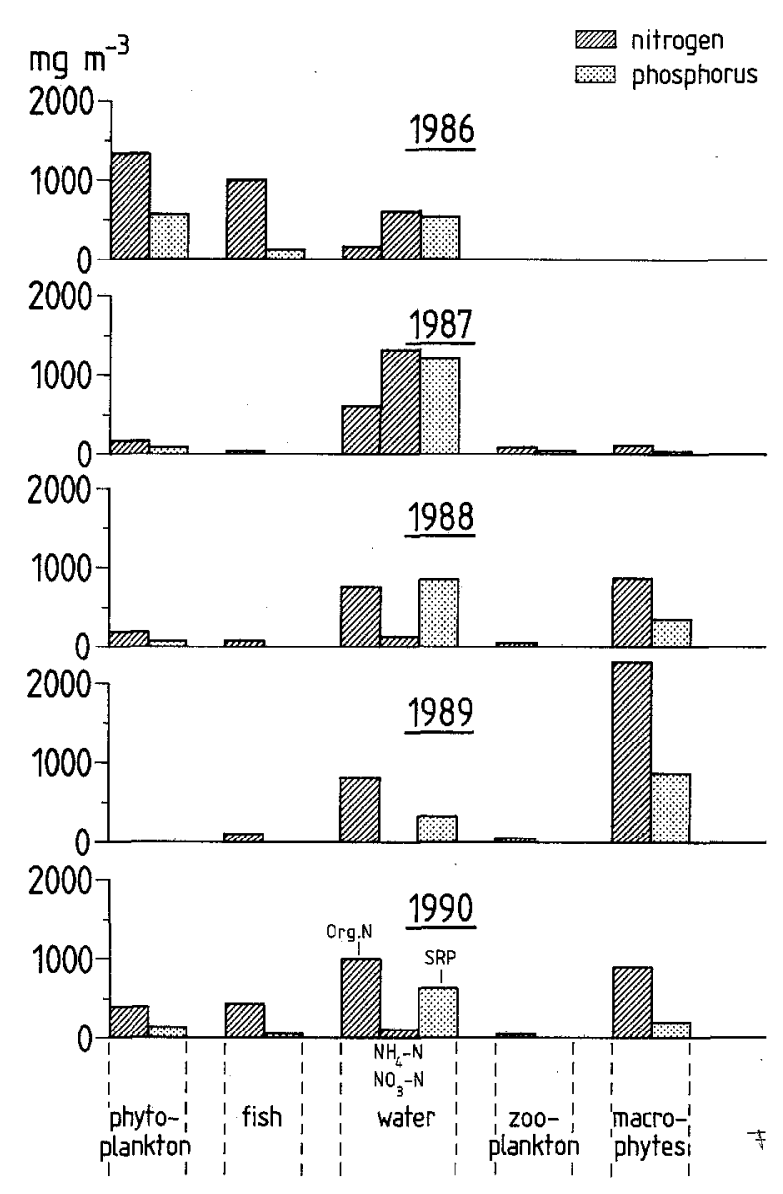

Fig. 2. The concentrations $\left(\mathrm{mg} \mathrm{m}^{-3}\right)$ of phosphorus and nitrogen in the different compartments of the ecosystem of Lake Zwemlust before (Aug. 1986) and after (Aug. 1987, 1988, 1989 and 1990) biomanipulation.

$30 \%$ of the nutrients was stored in phytoplankton and fish. The amount of dissolved organic $\mathrm{N}$ in the water increased from $600 \mathrm{mg} \mathrm{m}^{-3}$ in 1987 to $1100 \mathrm{mg} \mathrm{m}^{-3}$ in 1990 . Although in Lake Zwemlust the biomass of macrofauna and filamentous green algae increased after biomanipulation (Kornijow et al., 1990), their contribution to the total biomass and $\mathrm{N}$ and $\mathrm{P}$ contents was relatively small, and therefore not included in Fig. 2.

The changes in $\mathrm{N}$ and $\mathrm{P}$ content of the lake for the period April 1989-September 1989 may be derived from Table 1. The calculated values for the external load of $\mathrm{N}$ and $\mathrm{P}$ and the estimated values for the internal load are given in Fig. 3. From April to July 1989 the external load of $\mathrm{N}$ 
Table 1. The amount of nitrogen and phosphorus in $\mathrm{mg} \mathrm{m}^{-3}$ distributed over the different compartments of the ecosystem of Lake Zwemlust on three dates in 1989.

\begin{tabular}{|c|c|c|c|c|c|c|}
\hline & \multicolumn{2}{|l|}{12 Apr. } & \multicolumn{2}{|l|}{$5 \mathrm{Jul}$. } & \multicolumn{2}{|l|}{30 Aug. } \\
\hline & $\mathrm{N}\left(\mathrm{mg} \mathrm{m}^{-3}\right)$ & $P\left(\mathrm{mg} \mathrm{m}^{-3}\right)$ & $\mathrm{N}\left(\mathrm{mg} \mathrm{m}^{-3}\right)$ & $\mathrm{P}\left(\mathrm{mg} \mathrm{m}^{-3}\right)$ & $\mathrm{N}\left(\mathrm{mg} \mathrm{m}^{-3}\right)$ & $\mathrm{P}\left(\mathrm{mg} \mathrm{m}^{-3}\right)$ \\
\hline Phytoplankton & 67 & 17 & 63 & 53 & 123 & 80 \\
\hline Fish & 33 & 3 & 67 & 7 & 100 & 10 \\
\hline Org. $\mathrm{N}$ & 576 & 0 & 599 & 0 & 856 & 0 \\
\hline Water $\mathrm{NH}_{4}-\mathrm{N}$ & 107 & 0 & 30 & 0 & 67 & 0 \\
\hline $\mathrm{NO}_{3}-\mathrm{N}$ & 76 & 0 & 23 & 0 & 54 & 0 \\
\hline SRP & 0 & 323 & 0 & 300 & 0 & 266 \\
\hline Zooplankton & 77 & 10 & 27 & 3 & 80 & 14 \\
\hline Macrophytes & 120 & 30 & 5261 & 1399 & 2264 & 599 \\
\hline Total & 1056 & 383 & 6070 & 1762 & 3544 & 969 \\
\hline
\end{tabular}

and $\mathrm{P}$ to the lake was nearly one-third the amounts of $\mathrm{N}$ and $\mathrm{P}$ taken up by the macrophytes. E. nuttallii, the dominant species at that time, can take up nutrients from the sediment with their root system. However, during July-

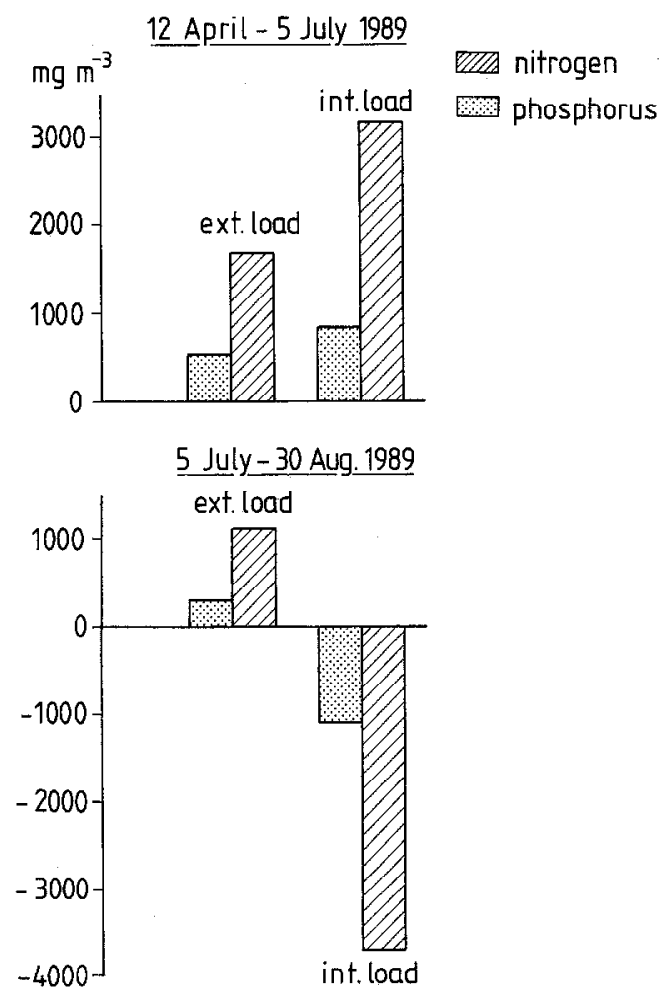

Fig. 3. The external and internal loads $\left(\mathrm{mg} \mathrm{m}^{-3}\right)$ of nitrogen and phosphorus to Lake Zwemlust, measured from 12 April to 5 July 1989 and from 5 July to 30 August 1989.
Sept. 1989, a negative internal load was found, probably due to the early decay of macrophytes in August. At that time most of the $\mathrm{N}$ and $\mathrm{P}$ were still fixed in the dead plants laying on the sediment.

The data obtained from the natural community bioassays have been used to depict changes in growth limitations of phytoplankton and macrophytes (Fig. 4). Before biomanipulation, light was the main growth rate limiting factor for the phytoplankton and the macrophytes. The low light conditions caused by phytoplankton blooms prevented the macrophytes from growing. After the manipulation, zooplankton grazing, and from

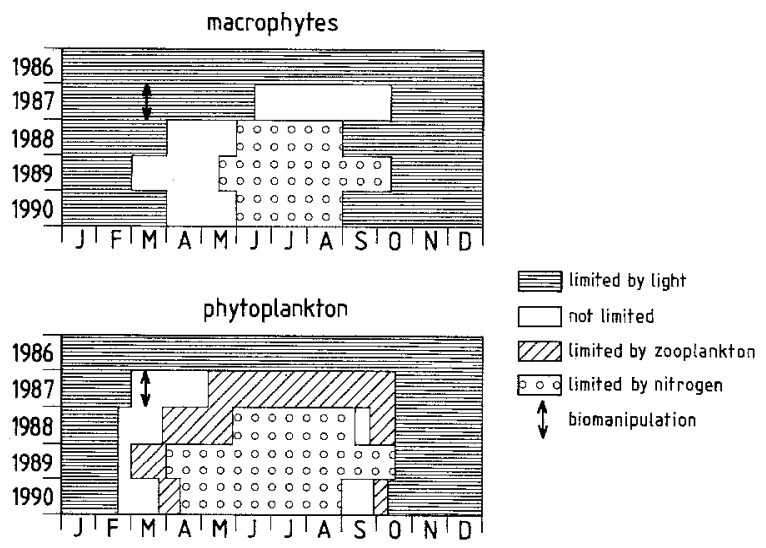

Fig. 4. Annual and seasonal changes in the factors limiting the macrophyte and phytoplankton growth in Lake Zwemlust before (1986) and after $(1987,1988,1989$ and 1990) biomanipulation. 
1988 onwards also $\mathrm{N}$ limitation, were the controlling factors for the phytoplankton community during the spring and summer. The high uptake of $\mathrm{N}$ by the macrophytes apparently caused an $\mathrm{N}$ limitation for the phytoplankton. Nitrogen-fixing cyanobacteria did not appear to be important for the nitrogen load to the lake since they were observed only in Aug. 1988 and in relatively small numbers (Van Donk, 1991).

The macrophytes were also mainly limited by nitrogen during the summer months. In 1990 , however, fish and/or waterfowl probably influenced the species composition of the macrophytes. In the cages placed on the lake bottom and serving as exclosures for larger fish and birds, Elodea reached a high abundance in 1990, but was completely absent outside the cages, where Ceratophyllum was the dominant species. Remains of plants were found in the stomachs of the $1^{+}$rudd (Klein Breteler, 1991). Further, frequently herbivorous coots (Fulica atra L.), sometimes more than 100 ind., were observed in Lake Zwemlust.

\section{Discussion}

Shifts in abundance and composition of phytoplankton and zooplankton, following a manipulation of the fish population, have been observed in several whole-lake food-web experiments (Shapiro, 1990; Benndorf, 1990). Most of these experiments, however, were followed over relatively short periods only. An enormous increase in macrophytes, as found in Lake Zwemlust, has been described in few other experiments in shallow lakes (Hanson \& Butler, 1990; Jeppesen et al., 1990; Meijer et al., 1989; Søndergaard et al., 1990). Nevertheless, little attention has been paid to the role of these macrophytes in changing the nutrient retention and cycling in the food-web, and in inducing long-term stability (Moss, 1990; Van Dijk \& Van Donk, 1991). An important question is the extent to which macrophyte stands act as sink or source for nutrients and promote denitrification in the course of the vegetation period. Dense stands of macrophytes can cause deficiencies of nutrients in the water (Boyd, 1971). In Lake Zwemlust, from April to July 1989, dense stands of $E$. nuttallii acted as a sink for both $\mathrm{N}$ and $\mathrm{P}$, withdrawing up to $c a 60 \%$ of its $\mathrm{N}$ and $\mathrm{P}$ contents directly and/or indirectly from the sediment (internal loading). In the period July-Sept. 1989, however, $60 \%$ of the $\mathrm{N}$ and $\mathrm{P}$ disappeared again from the macrophyte compartment due to leakage, decay and grazing which slightly increase the content of $\mathrm{N}$ and $\mathrm{P}$ in fish, phytoplankton, water and sediment (Table 1 and Fig. 3). At the end of the year only a part of the $\mathrm{N}$ and $\mathrm{P}$ from the decayed macrophytes ( $c a 30 \%$ of $\mathrm{N}$ and $60 \%$ of $\mathrm{P}$ ) was still found in the ecosystem (chiefly in dissolved form). The rest remained in the sediment and some per cent of $\mathrm{N}$ probably left the lakes's ecosystem by denitrification. The macrophyte compartment in Lake Zwemlust performed a similar function, i.e. improvement of water quality by changing nutrient retention and recycling in the food-web, as was attributed to land/inland water ccotoncs by Naiman et al. (1989).

The shift in dominance from $E$. nuttallii in 1989 to $C$. demersum in 1990 (Fig. 1) has probably been caused by selective grazing mainly of $1^{+}$rudd ( $\mathrm{ca}$ $257 \mathrm{~kg} \mathrm{ha}^{-1}$ in 1990) on Elodea. C. demersum is apparently not very edible for rudd due to its calcareous structure. This plant has no roots and is, therefore, not able to use nutrients from the sediment directly. Also grazing on macrophytes by herbivorous waterfowl may play a role. Hanson \& Butler (1990) found a dramatic increase in waterfowl that fed upon macrophytes in Lake Cristina after biomanipulation. Verhoeven (1978) calculated a consumption of $70 \mathrm{~g} \mathrm{DW}$ Ruppia spp. per 1 coot per day.

It is not clear whether this shift from Elodea to Ceratophyllum may result in negative or positive effects for the water quality of the lake. One likely positive effect is that Ceratophyllum can not take up nutrients from the sediment, so that the internal load of $\mathrm{N}$ and $\mathrm{P}$ to the lake may decrease. A positive property of Elodea, however, is its ability to compete with phytoplankton for nutrients by building up high biomass during summer. The shift in the zooplankton community in 1990 , from 
daphnids to bosminids, may also be the result of the increased predation, especially of $0^{+}$rudd ( $c a$ $125 \mathrm{~kg} \mathrm{ha}^{-1}$ ) on large-bodied daphnids. The relatively higher phytoplankton biomass in summer of 1990, as compared to previous years (Fig. 2), has apparently been one of the consequences of the above changes (mean chlorophyll-a conc. of $14 \mu \mathrm{g} 1^{-1}$ with a maximum on 8-29 of $35 \mu \mathrm{g} 1^{-1}$ ). Hence, the increased rudd population, consuming not only zooplankton but also Elodea, may lead to the return of the lake to its former state, dominated by phytoplankton blooms. Obviously the stocked pike population is not able to control the rudd population. Continuation of the monitoring programme will probably give more information on the question if regular fish stock management will be a necessary tool to keep this lake with a high nutrient load in its clear water state.

\section{Conclusions}

We may conclude from this study that fish manipulation in a eutrophic shallow lake can switch the lake from a turbid state (dominating by phytoplankton) to a clear water state (dominated by macrophytes). The macrophytes had a stabilizing function, acting as a sink for $\mathrm{N}$ and $\mathrm{P}$ and therefore changed the nutrient retention and cycling in the food web. However, it is unclear whether in the long-term the manipulated system will return to its initial turbid condition, or will stay in the clear water state.

\section{Acknowledgements}

We thank G. A. den Hartogh for his assistance in calculating the water and nutrient budgets, dr T. Ozimek for the macrophyte observations in 1988 and 1989, and K. Siewertsen for N and P measurements in seston and fish. Dr B. $\Lambda$. Faafeng, Dr O. F. R. van Tongeren, Dr J. Vijverherg and Prof. Dr W. J. Wolff made some useful suggestions on the last version of the typescript. The project was financially supported by the Province of Utrecht.

\section{References}

Benndorf J., 1990. Conditions for effective biomanipulation; conclusions derived from whole-lake experiments in Lurope. In R. D. Gulati, E. H. R. R. Lammens, M.-L. Meijer \& E. van Donk (eds), Biomanipulation - Tool for Water Management. Developments in Hydrobiology 61. Kluwer Academic Publishers, Dordrecht: 187-205. Reprinted from Hydrobiologia 200/201.

Boers, P., L. van Ballegooyen \& J. Uunk, 1991. Changes in phosphorus cycling in a shallow lake due to food web manipulations. Freshwat. Biol. 25: 9-20.

Boyd, C. E., 1971. The limnological role of aquatic macrophytes and their relationship to reservoir management. Reserv. Fish. Limnol. 8: 153-166.

Cooke, G. D., M. R. McComas, D. W. Waller \& R. H. Kennedy, 1977. The occurrence of internal phosphorus loading in two small eutrophic glacial lakes in north-eastern Ohio. Hydrobiologia 56: 129-135.

Gulati, R. D., 1989. Structure and feeding activity of zooplankton community in Lake Zwemlust, in the two years after biomanipulation. Hydrobiol. Bull. 23: 35-49.

Gulati, R. D., 1990. Structural and grazing responses of zooplankton community to biomanipulation of some Dutch water bodies. In R. D. Gulati, E. H. R. R. Lammens, M.-L. Meijer \& E. van Donk (eds), Biomanipulation - Tool for Water Management. Developments in Hydrobiology 61. Kluwer Academic Publishers, Dordrecht: 99-119. Reprinted from Hydrobiologia 200/201

Hanson, M. A. \& M. G. Butler, 1990. Early responses of plankton and turbidity to biomanipulation in a shallow prairie lake. In R. D. Gulati, E. H. R. R. Lammens, M.-L. Meijer \& E. van Donk (eds), Biomanipulation - Tool for Water Management. Developments in Hydrobiology 61. Kluwer Academic Publishers, Dordrecht: 317-327. Reprinted from Hydrobiologia 200/201.

Jeppesen, E., J. P. Jensen, P. Kristensen, M. Søndergaard, E. Mortensen, O. Sortkjaer \& K. Olrik, 1990. Fish manipulation as a lake restoration tool in shallow, eutrophic, temporate lakes 2: threshold levels, long-term stability and conclusions. In R. D. Gulati, E. H. R. R. Lammens, M.-L. Meijer \& E. van Donk (eds), Biomanipulation - Tool for Water Management. Developments in Hydrobiology 61. Kluwer Academic Publishers, Dordrecht: 219-227. Reprinted from Hydrobiologia 200/201.

Klein Breteler, J. G. P., 1991. The development of the fish stock in Lake Zwemlust in 1990 (in Dutch; English summary). OVB-Onderzoeksrapport 1990-03.

Kornijow, R., R. D. Gulati \& E. Van Donk, 1990. Hydrophytc-macroinvcrtcbratc interactions in Zwemlust, a lake undergoing biomanipulation. In R. D. Gulati, E. H. R. R. Lammens, M.-L. Meijer \& E. van Donk (eds), Biomanipulation - Tool for Water Management. Developments in Hydrobiology 61. Kluwer Academic Publishers, Dordrecht: 467-475. Reprinted from Hydrobiologia 200/201.

Meijer, M-L., A. J. P. Raat \& R. W. Doef, 1989. Restoration 
by biomanipulation of the Dutch shallow, eutrophic Lake Bleiswijkse Zoom: first results. Hydrobiol. Bull. 23: 49-59.

Moss, B., 1990. Engineering and biological approaches to the restoration from eutrophication of shallow lakes in which aquatic plant communities are important components. In R. D. Gulati, E. H. R. R. Lammens, M.-L. Meijer \& E. van Donk (eds), Biomanipulation - Tool for Water Management. Developments in Hydrobiology 61. Kluwer Academic Publishers, Dordrecht: 367-379. Reprinted from Hydrobiologia 200/201.

Naiman, R. J., H. Decamps \& F. Fournier, 1989. The role of land/inland watcr ceotones in landscape management and restoration: a proposal for collaborative research. MAB Digest 4 Unesco Paris, 94 pp.

Ozimek, T., E. Van Donk \& R. D. Gulati, 1990. Can macrophytes be useful in biomanipulation of lakes? The lake Zwemlust example. In R. D. Gulati, E. H. R. R. Lammens, M.-L. Meijer \& E. van Donk (eds), Biomanipulation - Tool for Water Management. Developments in Hydrobiology 61. Kluwer Academic Publishers, Dordrecht: 399-409. Reprinted from Hydrobiologia 200/201.

Scheffer, M., 1990. Multiplicity of stable states in freshwater systems. In R. D. Gulati, E. H. R. R. Lammens, M.-L. Meijer \& E. van Donk (eds), Biomanipulation - Tool for Water Management. Developments in Hydrobiology 61. Kluwer Academic Publishers, Dordrecht: 475-487. Reprinted from Hydrobiologia 200/201.

Shapiro, J., 1990. Biomanipulation: the next phase-making it stable. In R. D. Gulati, E. H. R. R. Lammens, M.-L. Meijer \& E. van Donk (eds), Biomanipulation - Tool for Water Management. Developments in Hydrobiology 61. Kluwer Academic Publishers, Dordrecht: 13-29. Reprinted from Hydrobiologia 200/201.

Shapiro, J. \& D. J. Wright, 1984. Lake restoration by biomanipulation: Round Lake, Minnesota, the first two years. Freshwat. Biol. 14: 371-383.
Søndergaard, M., E. Jeppesen, E. Mortensen, E. Dall, P. Kristensen \& O. Sortkjaer, 1990. Phytoplankton biomass reduction after planktivorous fish reduction in a shallow eutrophic lake: a combined effect of reduced internal P-loading and induced zooplankton grazing. In R. D. Gulati, E. H. R. R. Lammens, M.-L. Meijer \& E. van Donk (eds), Biomanipulation - Tool for Water Management. Developments in Hydrobiology 61. Kluwer Academic Publishers, Dordrecht: 229-241. Reprinted from Hydrobiologia 200/201.

Van Donk, E., 1991. Changes is community structure and growth limitation of phytoplankton due to top-down foodweb manipulation. Verh. int. Ver. Limnol. 24: 773-778.

Van Donk, E., A. Veen \& J. Ringelberg, 1988. Natural community bioassays to determine the abiotic factors that control phytoplankton growth and succession. Freshwat. Biol. 20: 199-210.

Van Donk, E., R. D. Gulati \& M. P. Grimm, 1989. Food-web manipulation in Lake Zwemlust: positive and negative effects during the first two years. Hydrobiol. Bull. 23: 19-34.

Van Donk, E., M. P. Grimm, R. D. Gulati \& J. P. G. Klein Breteler, 1990. Whole-lake food-web manipulation as a means to study community interactions in a small ecosystem. In R. D. Gulati, E. H. R. R. Lammens, M.-L. Meijer \& E. van Donk (eds), Biomanipulation - Tool for Water Management. Developments in Hydrobiology 61. Kluwer Academic Publishers, Dordrecht: 275-291. Reprinted from Hydrobiologia 200/201.

Van Dijk, G. M. \& E. Van Donk, 1991. Perspectives for submerged macrophytes in shallow lake restoration projects in The Netherlands. Hydrobiol. Bull. 24: 125-133.

Verhoeven, J. T. A., 1978. Natural regulation of plant biomass in a Ruppia dominated system. Proc. EWRS 5th Symp. on aquatic weeds: 53-61. 